\title{
Gender differences in nutritional status among under five children in rural areas of Bijapur district, Karnataka, India
}

\author{
Shashank Kumbarahalli Jawaregowda ${ }^{1}$, Mahabaleshwar Mahantappa Angadi ${ }^{2}$
}

\author{
${ }^{1}$ Assistant Professor, Department of Community Medicine, Adichunchanagiri Institute of Medical Sciences, B G \\ Nagar, Mandya, Karnataka, India \\ ${ }^{2}$ Professor \& HOD, Department of Community Medicine, BLDEU’s SBMPMC, Bijapur, Karnataka, India
}

Received: 09 August 2015

Accepted: 20 August 2015

\author{
*Correspondence: \\ Dr. Shashank K J, \\ E-mail: shashank.kj@gmail.com
}

Copyright: (C) the author(s), publisher and licensee Medip Academy. This is an open-access article distributed under the terms of the Creative Commons Attribution Non-Commercial License, which permits unrestricted non-commercial use, distribution, and reproduction in any medium, provided the original work is properly cited.

\begin{abstract}
Background: Malnutrition is frequently part of a vicious cycle that includes poverty and disease Socio-economic and political changes that improve health and nutrition can break the cycle, as can specific nutrition and health interventions. Malnutrition in children is a multifactorial causation. Hence this study was conducted to assess the role of gender in the nutritional status of the under five children. Objective: To assess the nutritional status of under five children and its relationship with the gender of the child.

Methods: A Cross Sectional Study was conducted across the ten Villages (2 Villages per Taluk) of Bijapur District from January 2013 to November 3013.A total of 1046 children (523 Males and 523 Females) were included in the study. WHO growth Charts was used to grade the severity of Malnutrition.

Results: The overall prevalence of underweight among under five children was 43\% (49.8\% male and $36.7 \%$ female). The association between underweight and gender was statistically significant. The overall prevalence of stunting among under five children was $38 \%$ (40.1\% male and 35.9\% female) and significantly associated with gender. The overall prevalence of wasting among children was $28.7 \%$ (36.5\% male and $21.2 \%$ female) and significantly associated with gender.

Conclusions: The median height and weight for the majority of children were within the normal range of WHO 2006 growth charts. Though it is believed that male children are better and well-nourished than females, the finding in our study is contradictory which a positive sign is.
\end{abstract}

Keywords: Gender, Female, Wasting, Stunting, Growth chart

\section{INTRODUCTION}

Nutrition has major effects on health. Nutrition refers to the availability of energy and nutrients to the body's cells in relation to body requirements. Malnutrition refers to any imbalance in satisfying nutrition requirements. Malnutrition among children is often caused by the synergistic effects of inadequate or improper food intake, repeated episodes of parasitic or other childhood diseases such as diarrhoea, and improper care during illness. Malnutrition is often cited as an important factor contributing to high morbidity and mortality among children in developing countries. ${ }^{1}$

Malnutrition is frequently part of a vicious cycle that includes poverty and disease. These factors are interlinked in such a way that each contributes to the presence and permanence of others. Socio-economic and political changes that improve health and nutrition can break the cycle, as can specific nutrition and health interventions. Malnutrition in children is the consequence of a food availability and dietary intake, breastfeeding, 
prevalence of infectious and parasitic diseases, access to health care, immunization gains major childhood diseases, vitamin A supplementation, maternal care during pregnancy, water supply and sanitation, socioeconomic status, and health-seeking behavior. Demographic characteristics such as the child's age and sex range of factors like poverty, ignorance, illiteracy. ${ }^{1,2}$

Gender differentials in nutritional status are reported during infancy, with discriminatory Breastfeeding and supplementation practices. Infant girls are breastfed less frequently, for shorter duration, and over shorter periods than boys. Girls and women face nutritional discrimination within the family, eating last and least resulting in nutritional deprivement, leading to anemia and malnourishment.

Gender inequalities in quantity and quality of food intake may contribute to under-nutrition mainly in settings where the girl child is still considered less important than the boy child.

The World Bank estimates (2009) reported that India is ranked 2nd in the world in the number of children suffering from malnutrition. The most growth retardation occurs by the age of two, and the damage is irreversible. The prevalence of underweight in rural area is $50 \%$ versus $38 \%$ in urban area and higher among girls (48.9\%) than boys $(45.5 \%){ }^{3}$

A major area of concern and focus in India is the remarkable degree of variation in demographic profile, socio- economic factors and cultural practices which play a role in gender bias.

\section{Objective:}

To assess the nutritional status of under five children and its relationship with the gender of the child.

\section{METHODS}

A Cross sectional study was conducted in the rural areas of Bijapur district from January 2013 to December 2013. Multiphase sampling technique was used as follows. Bijapur district has FIVE taluks. TWO primary health centers were selected from each taluk by using Simple Random Sampling (lottery method). A total of TEN primary health centers were selected. From each of this primary health center using Simple random sampling (lottery method) ONE village was selected for the study. So totally TEN villages across the Bijapur district were selected for the purpose of study.

Considering the prevalence of gender bias as $2.8 \% 4$ at $95 \%$ of confidence interval and at +1 margin of error, the sample size was 1045 .

Each village was visited in the first week of every month from January 2013 to November 2013. Data was collected by interview technique. The mothers were explained the purpose of the study and those consented to be a part of study was included. Information was collected in a pretested predesigned and semi structured questionnaire.

Proportionate sample size for the corresponding village was calculated based on the $0-5$ year population of that village. Equal number of boys and girls were selected from every village based on the sample size obtained.

WHO 5 (2006) growth charts was used to classify the children as normal ( $+2 \mathrm{SD}$ to $-2 \mathrm{SD})$, mild to moderate (-2 SD to $-3 \mathrm{SD}$ ) and severe (less than - $3 \mathrm{SD}$ ) malnourished. Underweight (weight for age), Stunting (height for age), Wasting (weight for height) was measured. Weight for height was calculated for the children aged above two years.

\section{RESULTS}

Among the under five children who participated in our study $197(18.9 \%)$ were less than 1 years of age, 207 $(19.8 \%)$ were between the age group of 12-23 months, $262(25.1 \%)$ in the age group of 24-35 months, $232(22.2$ $\%)$ were in the age group of 36-47 months, 147 (14\%) in the age group of $48-59$ months. The mean age of children in our study was 2.87 years $(+1.26)$.

Table 1: Distribution of children based on gender and underweight (weight for age).

\begin{tabular}{|llllll|}
\hline $\begin{array}{l}\text { Under } \\
\text { weight }\end{array}$ & Male & $\%$ & Female & $\%$ & Total \\
\hline Normal & 262 & 50.2 & 331 & 63.3 & $593(56.7 \%)$ \\
\hline $\begin{array}{l}\text { Mild to } \\
\text { moderate }\end{array}$ & 207 & 39.7 & 128 & 24.5 & $335(32.1 \%)$ \\
\hline Severe & 53 & 10.2 & 64 & 12.2 & $117(11.2 \%)$ \\
\hline Total & 522 & 100 & 523 & 100 & $1045(100 \%)$ \\
\hline
\end{tabular}

Chi square $=27.69, \mathrm{p}=0.000$

Table 2: Distribution of children based on gender and stunting (height for age).

\begin{tabular}{|llllll|}
\hline Stunted & Male & $\%$ & Female & $\%$ & Total \\
\hline Normal & 313 & 60.0 & 335 & 64.1 & $648(62 \%)$ \\
\hline $\begin{array}{l}\text { Mild to } \\
\text { moderate }\end{array}$ & 132 & 25.3 & 136 & 26.0 & $268(25.6 \%)$ \\
\hline Severe & 77 & 14.8 & 52 & 9.9 & $129(12.4 \%)$ \\
\hline Total & 522 & 100 & 523 & 100 & $1045(100 \%)$ \\
\hline
\end{tabular}

Chi square $=5.65, \mathrm{p}=0.059$

Out of the 522 males, $313(60 \%), 132(25.3 \%)$ and $77(14.8 \%)$ were normal, mild to moderately and severely stunted. Among 523 female children 335 (64.1\%), $136(26 \%)$ and $52(9.9 \%)$ were classified as normal, mild to moderately and severely stunted. The association was found to be statistically significant. 
Table 3: Distribution of children based on gender and wasting (weight for height) $n=814$.

\begin{tabular}{|lllllll|}
\multirow{2}{*}{ Wasted } & \multicolumn{5}{c}{ Gender } \\
& Male & $\%$ & Female & $\%$ & Total \\
\hline Normal & 256 & 63.5 & 324 & 78.8 & $580(71.3 \%)$ \\
\hline $\begin{array}{l}\text { Mild to } \\
\text { moderate }\end{array}$ & 116 & 28.8 & 73 & 17.8 & $189(23.2 \%)$ \\
\hline Severe & 31 & 7.7 & 14 & 3.4 & $45(5.5 \%)$ \\
\hline Total & 403 & 100 & 411 & 100 & $814(100 \%)$ \\
\hline
\end{tabular}

Chi square $=24.1, \mathrm{p}=0.000$

In our study wasting (weight for age) was found to be more common among male children than female children. Out of 403 males and 411 female children, 256 (63.5\%) male children and $324(78.8 \%)$ female children were classified as normal. $116(28.8 \%), 31(7.7 \%)$ of male children and $73(17.8 \%), 14(3.4 \%)$ of female children were mild to moderately and severely wasted respectively.

On applying chi square trend test it was found that as mothers age increases the association of mother age with underweight was found to be statistically not significant for both males $(\mathrm{p}=0.07)$ and females $(\mathrm{p}=0.88)$.

On applying chi square trend test it was found that as mothers age increases the association of mother age with stunting was found to be statistically not significant for both males $(\mathrm{p}=019)$ and females $(\mathrm{p}=0.22)$

On applying chi square trend test it was found that as mothers age increases the association of mother age with wasting was found to be statistically not significant for males $(p=0.75)$ and significant for females $(p=0.02)$.

On applying chi square trend test it was found that as mothers education increases the association of mother education with underweight was found to be statistically not significant for both males $(\mathrm{p}=0.50)$ and females $(\mathrm{p}$ $=0.88$ ).

On applying chi square trend test it was found that as mothers education increases the association of mother education with stunting was found to be statistically not significant for both males $(\mathrm{p}=0.66)$ and females $(\mathrm{p}$ $=0.08$ ).

On applying chi square trend test it was found that as mothers education increases the association of mother education with wasting was found to be statistically not significant for both males $(\mathrm{p}=0.43)$ and females $(\mathrm{p}$ $=0.11)$.

\section{DISCUSSION}

Study was done in the rural areas of Bijou district from January to November 2013. Interview technique was used to collect data for 1045 under five children from the mothers. Equal number of male (522) and female (523) children were included in the study. Children were almost uniformly distributed in all the age groups.

Table 4: Adjusted Odd's Ratio for weight for age (underweight).

\begin{tabular}{|llll|}
\hline Underweight & Gender* $^{*}$ & $\begin{array}{l}\text { Among } \\
\text { Literate } \\
\text { mothers \# }\end{array}$ & $\begin{array}{l}\text { Among } \\
\text { illiterate } \\
\text { mothers } \\
\#\end{array}$ \\
\hline $\begin{array}{l}\text { Adjusted } \\
\text { ODD'S Ratio }\end{array}$ & 1.68 & 1.90 & 1.50 \\
\hline
\end{tabular}

${ }^{\wedge}$ male as reference variable *odds ratio adjusted to mothers age, education and occupation \# odds ratio adjusted to mothers age and occupation

Table 5: Adjusted Odd's Ratio for height for age (stunting).

\begin{tabular}{|llll|}
\hline Stunted & Gender * & $\begin{array}{l}\text { Among } \\
\text { Literate } \\
\text { mothers \# }\end{array}$ & $\begin{array}{l}\text { Among } \\
\text { illiterate } \\
\text { mothers \# }\end{array}$ \\
\hline $\begin{array}{l}\text { Adjusted } \\
\text { ODD'S } \\
\text { Ratio^ }^{\wedge}\end{array}$ & 1.15 & 0.87 & 1.48 \\
\hline
\end{tabular}

${ }^{\wedge}$ male as reference variable $*$ odds ratio adjusted to mothers age, education and occupation \# odds ratio adjusted to mothers age and occupation

Table 6: Adjusted Odd's Ratio for weight for height (wasting).

\begin{tabular}{|lll|l|}
\hline Wasting & Gender* & $\begin{array}{l}\text { Among } \\
\text { Literate } \\
\text { mothers\# }\end{array}$ & $\begin{array}{l}\text { Among } \\
\text { illiterate } \\
\text { mothers \# }\end{array}$ \\
\hline $\begin{array}{l}\text { Adjusted } \\
\text { ODD'S } \\
\text { Ratio^ }^{\wedge}\end{array}$ & 1.54 & 1.29 & 2.29 \\
\hline
\end{tabular}

${ }^{\wedge}$ male as reference variable *odds ratio adjusted to mothers age, education and occupation \# odds ratio adjusted to mothers age and occupation

The overall prevalence of underweight among fewer than five children was $43 \%$ ( $49.8 \%$ male and $36.7 \%$ female). The association between underweight and gender was statistically significant. Mother age also had significant association with underweight among both the gender. The overall prevalence of stunting among under five children was $38 \%$ (40.1\% male and $35.9 \%$ female) and significantly associated with gender. The overall prevalence of wasting among children was $28.7 \%$ (36.5 $\%$ male and $21.2 \%$ female) and significantly associated with gender. Mother age had significant association with wasting among female children. The prevalence of Gender Bias among children with Underweight was $13.1 \%$, Stunting was $4.2 \%$ and Wasting was $15.3 \%$ favoring the female children. 
In our study, $49.9 \%$ male and $36.7 \%$ females were underweight, $40.1 \%$ male and $35.9 \%$ females were stunted and wasting was seen in $36.5 \%$ male and $21.2 \%$. Overall the prevalence of malnutrition in any form was more seen among the male children when compared to female children. Similar kind of results was also seen in the studies done by Sandi Kumar Ray et al, ${ }^{6}$ Dhananjay Phatak $^{7}$ and Suman Chakrabarty et al. ${ }^{8}$

In the studies done by Banerjee et al, ${ }^{9}$ Harishankar et al, ${ }^{10}$ Balani K D et al ${ }^{11}$ and Ndiklu et al ${ }^{12}$ the prevalence of malnutrition was more among female children when compared to male children contrasting to our study findings.

\section{CONCLUSION}

The median height and weight for the majority of children were within the normal range of WHO 2006 growth charts. Though it is believed that male children are better and well-nourished than females, the finding in our study is contradictory which a positive sign is. IEC activities should be enhanced so as to change the behaviour of mothers for the Prevention of malnourishment by improving the duration of breastfeeding, initiation of Weaning with protein energy rich diet at proper age, proper hygienic practices and to seek the timely reference from a qualified Doctor for the illness and proper adherence to the treatment . Most importantly all the IEC activities should be focusing on GENDER EQUALITY in all aspects.

Funding: No funding sources

Conflict of interest: None declared

Ethical approval: The study was approved by the Institutional Ethics Committee

\section{REFERENCES}

1. Mishra VK et al. Child Nutrition in India. National Family Health Survey Subjects Reports. International Institute for population Sciences, Mumbai.India.1999: June;14.

2. Ndiku M et al. Gender inequality in food intake and nutritional status of children under 5 years old in rural Eastern Kenya. European Journal of Clinical Nutrition. 2011;65:26-31.

3. The World Bank. Undernourished. Chapter 1. What Are The Dimensions Of The Undernutrition
Problem In India? [Internet].2014 [cited 2014 August 20]. Available from http://siteresources.worldbank.org/ SOUTHASIAEXT/Resources/2235461147272668285/ undernourished_chapter_1.pdf.

4. International Institute for Population Sciences (IIPS) and Macro International.2007. National Family Health Survey (NFHS-3), 2005-06: Government of India: Volume I. Mumbai: IIPS.

5. The WHO Child Growth Standards. World Health Organization. [Internet] 2014 [cited 2014 May 15] .Available from http://www.who.int/ child growth/standards/en/.

6. Ray S K, Biwa's A B, Gupta S D, Mukherjee D. Rapid Assessment of Nutritional Status and Dietary Pattern in Municipal Area. Indian Journal of Community Medicine.2000;25(1):14-8.

7. PathakD. Gender Disparity in Health and Nutritional Status in Children Under Five Years of Age in a Rural Community: A Cross Sectional Study [MPH Thesis]. Belgaum; KLE University: 2011.

8. Chakraborty S, Gupta S B, Chaturvedi B, Chakraborty S K. A Study of Protein Energy Malnutrition (PEM) in Children (0-6 Year) in a Rural Population of Jhansi District (U.P).Indian Journal of Community Medicine. 2006;31(4):291-2.

9. Banerjee B, Bandyopadhyay L. Gender Difference in Nutritional Status. Indian Pediatrics.2005;42:400.

10. Harishankar, Dwivedi S, Dabral SB, Walia DK. Nutritional Status of Children Under 6 Years of Age. Indian J Prev Soc Med. 2004;3(4):156-62.

11. Bhalani K D, Kotecha P V. Nutritional Status and Gender Differences in the Children of less than 5 years of Age Attending ICDS Anganawad's in Vadodara City. Indian Journal of Community Medicine.2002;27:124-9.

12. Ndiklu M, Siegl K J, Singh P, Sabate J. Gender Inequalities in Food Intake and Nutritional Status of Children Under Five Years Old in Rural Eastern Kenya. European Journal of Clinical Nutrition.2011;65:26-31.

Cite this article as: Jawaregowda SK, Angadi MM. Gender differences in nutritional status among under five children in rural areas of Bijapur district,

Karnataka, India. Int J Community Med Public Health 2015;2:506-9. 